\title{
KEWENANGAN DPR DALAM RATIFIKASI PERJANJIAN INTERNASIONAL PASCA TERBITNYA PUTUSAN MAHKAMAH KONSTITUSI
}

\author{
NO. 13/PUU-XVI/2018
}

\author{
Ari Wuisang \\ Fakultas Hukum Universitas Pakuan, \\ Jalan Pakuan No. 1 Bogor 16143 \\ ari.wuisang@unpak.ac.id
}

Naskah diterima : 01/05/2019, revisi : 12/06/2018, disetujui 15/06/2019

\begin{abstract}
ABSTRAK :
Persoalan ratifikasi perjanjian internasional merupakan wilayah persentuhan antara hukum tata negara dengan hukum internasional. Pengaturan dan praktik perjanjian internasional di Indonesia mengalami perkembangan dengan terbitnya Putusan MK No. 13/PUU-XVI/2018 tentang Pengujian UU No. 24 Tahun 2000 tentang Perjanjian Internasional terhadap UUD. Putusan tersebut telah menimbulkan perumusan hukum baru terhadap kriteria perjanjian yang memerlukan persetujuan DPR dan mekanisme ratifikasinya baik internal maupun eksternal. Hal ini ibarat pedang bermata dua, karena selain menyelesaikan problematika praktik ratifikasi yang terjadi selama ini, sekaligus juga membuka isu-isu hukum baru.

Kata kunci : ratifikasi, perjanjian internasional, uji materiil, Mahkamah Konstitusi.
\end{abstract}

\section{A. Eksistensi Perjanjian Internasional dalam Lingkaran Masyarakat Internasional}

Manusia sebagai makhluk sosial selalu membutuhkan hubungan dengan manusia lainnya. Di dalam masyarakat bagaimanapun sederhananya, para anggota masyarakat itu membutuhkan hubungan satu sama lain. ${ }^{1}$ Oleh sebab itu, untuk mengatur hubunganhubungan dalam kehidupan bersama masyarakat tersebut, fungsi hukum menjadi krusial. 2 Sifat saling membutuhkan juga dialami oleh suatu negara. Sebagai anggota masyarakat internasional, suatu negara tidak dapat hidup tanpa adanya hubungan dengan anggota masyarakat internasional lainnya. ${ }^{3}$ Dengan perkataan lain, hubungan

\footnotetext{
1 Sri Setianingsih Suwardi, Pengantar Hukum Organisasi Internasional (Jakarta : UI Press, 2004), hal. 1.

2 Ali Sastroamidjojo, Pengantar Hukum Internasional (Jakarta : Bhratara, 1971), hal. 1.

$3 \mathrm{Hal}$ ini sejalan dengan teori hukum internasional yang disebut Teori Fait Social. Menurut teori ini, --yang dikembangkan oleh Mazhab Perancis dengan pemukanya Fauchille, Scelle dan Duguit-- sebagai makhluk biologis, manusia memiliki pelbagai kebutuhan biologis, demikian pula sebagai makhluk sosial. Kedua macam kebutuhan itu tidak dapat dipenuhi sendiri-sendiri, melainkan hanya dapat dipenuhi dalam keterkaitan dengan sesamanya. Hal ini menunjukkan, bahwa manusia dalam menjalankan kehidupannya harus memenuhi kebutuhan-kebutuhan maupun kepentingannya. Dalam usaha untuk memenuhinya itu, supaya tidak saling bertentangan atau bertabrakan antara satu dengan lainnya, mereka membutuhkan
} 
antar negara (internasional) yang berlangsung pada prinsipnya dilandasi oleh kebutuhan timbal balik masing-masing negara. Ketidakmerataan sumber daya ditengarai sebagai nalar berlangsungnya hubungan internasional tersebut. 4

Dalam interaksi antar negara sangat sulit diharapkan akan selalu terjadi keselarasan kepentingan. Keadaan sebaliknya, konflik kepentingan antar negara sangat besar kemungkinannya untuk terjadi. Meminimalisir atau setidaknya memberikan solusi jika terdapat keadaan yang demikian menjadikan hukum internasional sebagai keniscayaan bagi pergaulan hidup negara-negara dalam masyarakat internasional. 5 Oleh sebab itu, seperti dikatakan oleh Wirjono Prodjodikoro, bahwa tujuan hukum internasional adalah untuk mengejar keselamatan dan tata tertib dalam masyarakat dunia, yang anggotanya terdiri dari pelbagai bangsa. 6

Seperti halnya hukum nasional yang memiliki sumber hukum, hukum internasional pun memiliki sumber hukum. Pada umumnya, saat berbicara tentang sumber-sumber hukum internasional, maka orang menunjuk kepada Pasal 38 ayat (1) Statuta Mahkamah Internasional yang menentukan :

Mahkamah Internasional, dalam memutus sengketa berdasarkan hukum internasional yang diserahkan kepadanya, akan menerapkan :

a. Perjanjian internasional baik umum maupun khusus yang menetapkan peraturan yang diakui secara tegas oleh negara-negara yang berselisih;

b. Kebiasaan internasional, sebagai bukti praktik umum yang diterima sebagai hukum;

c. Prinsip-prinsip hukum umum yang diakui oleh bangsa-bangsa beradab;

pengaturan-pengaturan yang berupa kaidah-kaidah hukum, supaya terwujud kehidupan sosial yang aman, damai, adil, tenteram. Jika semua itu tidak diatur sedemikian rupa, maka tidak akan terwujud kehidupan bersama seperti yang mereka inginkan. Kebutuhan dan naluri sosial manusia sebagai orang seorang menurut Teori Fait Social juga dimiliki oleh bangsa-bangsa. Lihat, I Wayan Parthiana, Pengantar Hukum Internasional (Bandung : Mandar Maju, 2003), hal. 32. Lihat juga, Mochtar Kusuma'atmadja dan Etty R. Agoes, Pengantar Hukum Internasional (Bandung : Alumni, 2003), hal. 53.

4 Titon Slamet Kurnia, Pengantar Sistem Hukum Indonesia (Bandung : Alumni, 2009), hal. 34.

$5 \mathrm{lbid}$., hal. 109. Hukum internasional merupakan istilah yang pertama kali diperkenalkan oleh Jeremy Bentham, seorang ahli hukum sekaligus filsuf utiltarianisme Inggris yang jenial pada tahun 1789. Lihat, Mark W. Janis, An Introduction to International Law (Boston Toronto : Litte Brown and Company, 1988), hal. 1. Di samping istilah hukum internasional, dikenal pula istilah-istilah serupa yang lebih klasik sepert hukum bangsa-bangsa (the law of nations/ius gentium) dan hukum antar negara (inter states law). Istilah-istilah klasik tersebut masih mengandung makna, bahwa hubungan-hubungan hukum yang tercakup didalamnya masih terbatas hanya hubungan-hubungan hukum antara bangsa-bangsa atau negara-negara saja. Adapun istilah hukum internasional sifatnya lebih modern dan menurut Mochtar Kusuma'atmadja istilah "internasional" sudah lazim dipakai orang untuk segala hal atau peristiwa yang melintasi batas wilayah suatu negara. Dengan kata lain, istilah ini paling mendekati kenyataan dikaitkan dengan perkembangan sifat hubungan dan masalah masyarakat internasional saat ini, yang ditandai dengan semakin bertambahnya subjek-subjek hukum tersebut (tidak hanya negara saja), serta semakin banyaknya bermunculan prinsip-prinsip dan kaidah-kaidah hukum internasional baru, yang semuanya menunjukkan semakin kompleksnya kehidupan masyarakat internasional. Lihat juga, I Wayan Parthiana, Pengantar Hukum Internasional..., op.cit., hal. 10-11; Mochtar Kusuma'atmadja dan Etty R. Agoes, Pengantar Hukum Internasional..., op.cit., hal. 5-6.

6 Wirjono Prodjodikoro, Azaz-Azaz Hukum Publik Internasional (Jakarta : Pembimbing Masa, 1967), hal. 9-10. 
d. Tunduk pada ketentuan Pasal 59, putusan dan ajaran (karya hukum) para penulis yang paling terkemuka dari berbagai bangsa sebagai sumber hukum tambahan untuk menentukan kaidah hukum. ${ }^{7}$

Berdasarkan ketentuan Pasal 38 ayat (1) di atas, maka jelaslah bahwa perjanjian internasional merupakan salah satu sumber hukum internasional. Dalam masyarakat internasional dewasa ini, perjanjian internasional memainkan peranan yang sangat penting dalam mengatur kehidupan dan pergaulan antar negara. Melalui perjanjian internasional, tiap negara menggariskan kerjasama mereka, mengatur berbagai kegiatan, menyelesaikan berbagai masalah demi kelangsungan hidup masyarakat itu sendiri. 8

Dalam dunia yang ditandai saling ketergantungan dewasa ini, tidak ada satu negara yang tidak mempunyai perjanjian dengan negara lain dan tidak ada satu negara yang tidak diatur oleh perjanjian dalam kehidupan internasionalnya. ${ }^{9}$ Oleh sebab itu, selama masih tetap berlangsungnya hubungan-hubungan antara bangsa-bangsa atau negara-negara di dunia ini, selama itu pula masih akan selalu muncul perjanjianperjanjian internasional. 10 Ali Sastroamidjojo menyebut perjanjian internasional sebagai bentuk hubungan antar-negara yang paling penting. ${ }^{11}$ Georg Schwarzenberger pun mengatakan hal senada,..."treaties are the primary source of international law". 12 Demikian pula halnya dengan G.I. Tunkin, "secara proporsional perjanjian internasional

\footnotetext{
${ }^{7}$ Statuta Mahkamah Internasional merupakan bagian tak terpisahkan dari Piagam PBB. Mahkamah Internasional sendiri secara struktur organisasi merupakan salah satu alat kelengkapan utama (primair organ) PBB.

8 Boer Mauna, Hukum Internasional Pengertian, Peranan dan Fungsi dalam Era Dinamika Global (Bandung : Alumni, 2000), hal. 82. Sumaryo Suryokusumo merinci masalah-masalah yang diatur dalam perjanjian internasional, yaitu masalah politik, ekonomi perdagangan, sosial, kebudayaan dan berbagai persoalan ilmu pengetahuan dan teknologi. Daftar macam perjanjian juga hampir tidak ada akhirnya, dari perjanjian tentang persekutuan militer, pengaturan perlucutan senjata, perilaku peperangan, membuat perdamaian, jaminan terhadap netralitas, penyelesaian sengketa perbatasan, ekstradisi, hubungan diplomatik dan konsuler, pelayaran dan lalu lintas perkapalan, penerbangan, bea cukai, hak cipta, pertukaran budaya, bantuan ekonomi dan teknik, masalah pengungsi, timbangan dan ukuran, perhubungan dan topik-topik khusus lainnya. Lihat, Sumaryo Suryokusumo, Hukum Perjanjian Internasional, (Jakarta : PT Tata Nusa, 2008), hal. 5-6. Bahkan, substansi yang diatur dalam perjanjianperjanjian internasional tidak hanya masalah-masalah dan objek-objek yang ada dibumi saja, tetapi sudah meluas dengan mencakup objek-objek di luar planet bumi, seperti tentang bulan, matahari dan benda-benda angkasa lainnya. Lihat juga, I Wayan Parthiana, Hukum Perjanjian Internasional Bagian 1 (Bandung : Mandar Maju, 2002), hal. 3. Lebih jauh dari itu, hukum internasional sekarang ini tidak hanya mengatur tingkah laku suatu negara terhadap negara lain, melainkan juga mengatur perbuatan negara terhadap dirinya sendiri, perbuatan negara terjadap warga negaranya dan wilayahnya (HAM dan lingkungan hidup) atau pilihan negara terhadap sistem pemerintahannya (demokrasi atau tidak). Oleh sebab itu, persoalan-persoalan yang secara tradisional digolongkan sebagai urusan domestik, saat ini sudah menjadi perhatian hukum internasional. Lihat juga, Damos Dumoli Agusman, Hukum Perjanjian Internasional Kajian Teori dan Praktik Indonesia (Jakarta : Refika Aditama, 2010 ), hal. 2.

9 Boer Mauna, Hukum Internasional Pengertian, Peranan..., op.cit., hal. 82.

10 I Wayan Parthiana, Hukum Perjanjian Internasional Bagian 1..., op.cit., hal. 1.

11 Ali Sastroamidjojo, Pengantar Hukum Internasional..., op.cit., hal. 146.

12 F.A. Whisnu Situni, Identifikasi dan Reformulasi Sumber-Sumber Hukum Internasional (Bandung : Mandar Maju, 1989), hal. 31. Lihat juga, Sefriani, Hukum Internasional Suatu Pengantar (Jakarta : PT RajaGrafindo Persada, 2010), hal. 28.
} 
pada masa kini menduduki tempat yang utama dalam hukum internasional sebagai akibat dari munculnya secara meluas persetujuan-persetujuan internasional". 13

Sifat heterogen masyarakat internasional sangat berperan dalam menjadikan perjanjian internasional sebagai sumber utama dari hukum internasional, terutama hukum internasional umum. Perjanjian multilateral khususnya yang memiliki sifat demokratik dalam arti bahwa seluruh negara mempunyai kesempatan untuk berperan serta di dalam pembuatannya, dapat memberikan sumbangan terhadap proses pembentukan hukum internasional. Alasan ini pulalah yang membuat perjanjian internasional dikehendaki oleh kebanyakan negara non-barat. ${ }^{14}$

Kelebihan-kelebihan lainnya dari perjanjian internasional yaitu :

1. Bentuknya yang tertulis; 15

2. Proses pembentukan perjanjian relatif lebih cepat; 16

3. Instrumen bahasa yang digunakan di dalam perjanjian internasional merupakan metode yang lebih jelas dan terpercaya untuk menyampaikan ukuran-ukuran umum perilaku dibandingkan dengan preseden atau contoh-contoh yang menjadi dasar kebiasaan; 17

4. Sebagai pengubah konsep. Hukum internasional sebagai instrumen politik memiliki manfaat untuk mengubah atau memperkenalkan suatu ketentuan, asas, kaidah atau konsep. 18

\section{B. Indonesia dan Hukum Perjanjian Internasional}

Hukum perjanjian internasional merupakan salah satu cabang dari hukum internasional. Sebagai negara yang telah merdeka lebih dari 50 tahun, persoalan perjanjian internasional bukanlah hal baru. Namun, sukar dibantah bahwa bidang ini belum terlalu populer dan kurang diminati di Indonesia, karena pada umumnya dianggap sebagai ilmunya para diplomat dan pejabat organisasi internasional seperti

13 I Wayan Parthiana, Hukum Perjanjian Internasional Bagian 1..., op.cit., hal. 3.

14 G.J.H. van Hoof, Rethinking The Sources of International Law (Pemikiran Kembali Sumber-Sumber Hukum Internasional), diterjemahkan oleh Hata (Bandung : Alumni, 2000), hal. 242.

15 Sefriani, Hukum Internasional..., op.cit., hal. 28. op.cit., hal. 240.

${ }^{16}$ F.A. Whisnu Situni, Identifikasi dan Reformulasi..., op.cit., hal. 31. Lihat juga, G.J.H. van Hoof, Pemikiran Kembali...,

17 Ibid., hal. 242.

18 Hikmahanto Juwana, Hukum Internasional Dalam Perspektif Indonesia Sebagai Negara Berkembang (Jakarta : Yarsif Watampone, 2010), hal. 27. Sebagai contoh, perjuangan Indonesia dalam memasukkan konsep negara kepulauan ke dalam hukum internasional universal yang akhirnya berhasil diakomodasi dalam Konvensi Hukum Laut PBB 1982. 
PBB serta hanya dibutuhkan oleh kalangan terbatas sehingga merasa tidak diperlukan oleh praktisi hukum lainnya. Di lingkungan pemerintahan sendiri, secara umum, kebutuhan untuk mendalami tentang hukum perjanjian internasional masih terdapat pada kalangan terbatas seperti Kementerian Luar Negeri dan masih belum merata di kementerian lainnya. 19

Perjanjian internasional yang dibuat Indonesia, yang telah semakin meningkat jumlahnya dewasa ini, pada hakikatnya bersifat lintas sektor dan menjamah beberapa disiplin ilmu hukum di Indonesia, seperti hukum tata negara, hukum administrasi negara, hukum ekonomi dan bahkan hukum perdata. Pada masa reformasi, keikutsertaan Indonesia dalam perjanjian internasional terutama didominasi oleh perjanjian ekonomi, investasi dan perdagangan. Selain itu, jumlah perjanjian di bidang HAM dan lingkungan hidup yang diratifikasi oleh Indonesia juga meningkat. Menurut catatan Treaty Room Kementerian Luar Negeri, sampai pada Desember 2009 telah tercatat sekitar 4000 perjanjian yang dibuat Indonesia. 20

Oleh sebab itu, Jimly Asshiddiqie mengakui bahwa perkembangan hukum internasional dewasa ini terus meningkat, sehingga pada aspek-aspek tertentu kedudukannya menjadi semakin kuat dan bahkan lebih kuat dari hukum nasional. Misalnya, di bidang Hak Asasi Manusia, terorisme, sistem keuangan dan perdagangan dan hukum internasional telah berkembang sangat kuat mengatasi hukum nasional. ${ }^{21}$ Berbagai alasan dikemukakan mengenai perlunya Indonesia meratifikasi berbagai perjanjian internasional yang bersifat multilateral. Mulai dari upaya mengangkat citra Indonesia di dunia internasional, desakan dari para penggiat lembaga swadaya masyarakat hingga kebutuhan nyata. ${ }^{22}$

Namun, proses ratifikasi perjanjian internasional di Indonesia ternyata menimbulkan masalah cukup kompleks, diantaranya menyangkut tidak jelasnya pembedaan antara prosedur internal dan prosedur eksternal dalam tahap-tahap ratifikasi, menyangkut kapasitas DPR dan juru runding (delegasi) Indonesia dalam

19 Sefriani, Hukum Internasional..., op.cit., hal. 34. Lihat juga, Damos Dumoli Agusman, Hukum Perjanjian Internasional..., op.cit., hal. 1.

20 Damos Dumoli Agusman, Hukum Perjanjian Internasional..., op.cit., hal. 1.

21 Jimly Asshiddiqie, Green Constitution Nuansa Hijau Undang-Undang Dasar Negara Republik Indonesia Tahun 1945 (Jakarta : PT RajaGrafindo Persada, 2009), hal. 2.

22 Hikmahanto Juwana, "Konsekuensi Ratifikasi Perjanjian Internasional", http://www.seputarindonesia.com/edisicetak/content/view/181327/, diakses tanggal 23 Januari 2011. 
membahas substansi perjanjian yang hendak diratifikasi dan ketidakjelasan mengenai perlu tidaknya transformasi (penterjemahan) ketentuan perjanjian ke dalam perundang-undangan nasional. Menurut Hikmahanto Juwana, pengalaman menunjukkan pemerintah dan DPR lambat dan kurang responsif dalam upaya transformasi yang dipersyaratkan. ${ }^{23}$ Selain itu, dengan lahirnya Mahkamah Konstitusi (MK) dalam sistem ketatanegaraan Indonesia juga menimbulkan masalah tersendiri dalam bidang perjanjian internasional. seperti diketahui, salah satu kewenangan MK adalah menguji undang-undang terhadap Undang-Undang Dasar. Dalam hal suatu ketentuan traktat yang telah diratifikasi oleh Pemerintah Indonesia dianggap bertentangan dengan UUD Tahun 1945, apakah MK dapat menguji substansi (materi muatan) perjanjian internasional melalui undang-undang prosedur internal (undangundang approval DPR) ? ${ }^{24} \mathrm{Hal}$ ini masih menjadi perdebatan hingga sekarang.

\section{Persetujuan untuk Terikat oleh Perjanjian Internasional dan Konsepsi Ratifikasi}

Menurut M. Afif Hasbullah, secara etimologi ratifikasi berasal dari bahasa latin yaitu "ratificare" yang terbentuk dari kata ratus yang berarti dimantapkan (fixed) dan facto yang berarti dibuat atau dibentuk (made). Jadi secara harfiah ratifikasi dapat berarti dibuat mantap atau disahkan melalui persetujuan (make valid by approving), dalam hal ini jika suatu perjanjian internasional telah ditandatangani, maka diperlukan suatu kekuatan secara hukum agar dapat berlaku secara mantap melalui persetujuan yang dilakukan dengan lembaga ratifikasi. Ratifikasi itu sendiri dalam bahasa latin mempunyai dua arti, pertama, ratum babare dan ratum ducere, ratifikasi dalam hal ini bersifat deklarator karena hanya mengesahkan suatu perjanjian yang telah disepakati oleh wakil-wakil negara, kedua, ratum facare dan ratum alicui esse, ratifikasi dalam hal ini bersifat konstitutif karena merupakan pengesahan semua ketentuan yang tercantum dalam perjanjian, yang berarti dapat mengikat bagi negara peserta. 25

$23 \mathrm{Ibid}$.

24 Undang-undang prosedur internal atau undang-undang approval DPR merupakan output dari persetujuan DPR. Artinya, setelah suatu perjanjian internasional ditandatangani oleh pemerintah (eksekutif), maka kemudian pemerintah meminta konfirmasi kepada DPR apakah lembaga perwakilan rakyat ini mau menyetujui perjanjian tersebut menjadi bagian dari hukum nasional atau sebaliknya, menolak. Dalam hal DPR menyetujui, maka persetujuan tersebut dikukuhkan melalui undang-undang. Oleh sebab itu, undang-undang tersebut merupakan"jubah" dari persetujuan DPR.

25 Saharuddin Daming, "Sekapur Sirih tentang Pranata Ratifikasi dan Perjanjian Internasional", http://docs.google.com/viewer?a=v\&q=cache:OyNWWi x0u0J:www.komnasham.go.id/publikasi/doc download/47-ratifikasi- 
Pembuatan perjanjian internasional dilakukan melalui tahap-tahap tertentu dan dapat berupa perjanjian secara bilateral, multilateral terbatas, multilateral universal, dalam kerangka konferensi internasional dan/atau kerangka organisasi internasional. Oleh sebab itu, sangat dimungkinkan ada perbedaan-perbedaan teknis dalam pembuatannya. Namun, secara umum dapatlah dikemukakan tahap-tahap pembuatan perjanjian internasional sebagai berikut :

1. Pendekatan informal menuju langkah formal;

2. Penunjukkan wakil-wakil yang akan mengadakan perundingan;

3. Kuasa penuh (full power) dan pelaksanaan perundingan (negotiation);

4. Penerimaan naskah perjanjian (adoption of the text);

5. Pengesahan bunyi naskah perjanjian (authentification of the text);

6. Persetujuan untuk terikat pada perjanjian (consent to be bound by a treaty);

7. Mulai berlakunya perjanjian internasional (enter into force);

8. Pendaftaran (registered) dan publikasi (published);

9. Pensyaratan (reservation). ${ }^{26}$

Berbicara tentang ratifikasi (ratification), maka berbicara tentang tahap persetujuan untuk terikat oleh perjanjian internasional (consent to be bound by a treaty). Persetujuan untuk terikat oleh perjanjian dapat diberikan dengan berbagai macam cara, dan cara mana yang hendak digunakan bergantung kepada kehendak negara-negara peserta pada waktu perjanjian itu diadakan. ${ }^{27}$ Selain itu, unsur materi muatan perjanjian juga acapkali turut memberikan andil dalam penentuan cara persetujuan demikian. Dalam Pasal 11 Konvensi Wina 1969 tentang Hukum Perjanjian, ditegaskan beberapa cara untuk menyatakan persetujuan untuk terikat pada perjanjian, yaitu :

1. Penandatanganan;

2. Pertukaran instrumen yang membentuk perjanjian;

3. Ratifikasi;

4. Akseptasi;

5. Persetujuan atau aksesi; atau

6. Dengan cara lain yang disepakati.

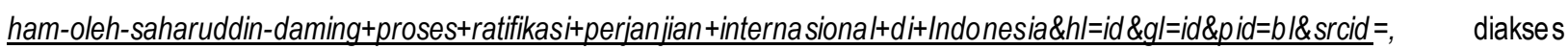
tanggal 3 Juni 2011.

26 I Wayan Parthiana, Hukum Perjanjian Internasional Bagian 1..., op.cit., hal. 94. Lihat juga, Mochtar Kusuma'atmadja dan Etty R. Agoes, Pengantar Hukum Internasional..., op.cit., hal. 125-130; J.G. Starke, An Introduction to International Law (Pengantar Hukum Internasional) 2, diterjemahkan oleh Bambang Iriana Djajaatmadja (Jakarta : Sinar Grafika, 2003), hal. 608.

27 Lihat, Mark W. Janis, An Introduction to International Law..., op.cit., hal. 10. Lihat juga, Mochtar Kusuma'atmadja dan Etty R. Agoes, Pengantar Hukum Internasional..., op.cit., hal. 128. 
UU No. 24 Tahun 2000 tentang Perjanjian Internasional 28 juga mengadopsi model yang terdapat pada Konvensi Wina 1969. Pasal 3 undang-undang tersebut menentukan :

Berlakunya perjanjian internasional terhadap Indonesia dapat dilakukan melalui :

a. Penandatanganan;

b. Pengesahan;

c. Pertukaran dokumen perjanjian/nota diplomatik;

d. Cara-cara lain sebagaimana disepakati para pihak dalam perjanjian internasional.

Kritik yang dapat diajukan terhadap Pasal 3 di atas yaitu tidak tepat apabila dikatakan "berlakunya perjanjian...", karena dengan dilakukannya cara tersebut belum tentu menandakan berlakunya perjanjian. Mungkin saja, misalnya, perjanjian tersebut mulai berlaku 6 (enam) bulan setelah pertukaran Piagam Ratifikasi, atau berlaku setelah terkumpulnya (tersimpannya) 35 Piagam Ratifikasi atau bahkan berlaku ke-sekian hari setelah terkumpulnya Piagam Ratifikasi dan sebagainya. ${ }^{29}$ Oleh sebab itu, istilah yang tepat bukan "berlakunya perjanjian..." tetapi harusnya "persetujuan untuk terikat oleh perjanjian..." Dalam hukum internasional, antara "mulai mengikatnya perjanjian internasional" dengan "mulai berlakunya perjanjian internasional" dimungkinkan untuk berbeda, walaupun tidak menutup kemungkinan terjadi bersamaan.

Hukum internasional hanya menyebutkan keharusan dan cara-cara persetujuan negara, sedangkan hukum nasional yang harus menentukan kekuasaan negara yang berwenang untuk memberikan persetujuan tersebut dan yang mengatur prosedurnya. 30 Dalam pengaturan dan praktik perjanjian internasional di Indonesia, ratifikasi diterjemahkan sebagai "pengesahan". Pasal 1 angka (2) UU No. 24 Tahun 2000 tentang

28 LN Tahun 2000 No. 185, TLN No. 4012.

29 Perlu diperhatikan, perjanjian-perjanjian internasional yang menggunakan prosedur penyimpanan (pengumpulan) Piagam Ratifikasi umumnya adalah perjanjian multiateral umum dan terbuka yang substansinya tergolong besar dan penting, sesuai dengan ruang lingkup, maksud maupun tujuan dari perjanjian itu sendiri. Dalam perjanjian seperti ini, karena substansinya yang demikian besar dan penting, maka tidaklah mungkin untuk mengharapkan negara-negara agar segera menyatakan persetujuannya untuk terikat pada perjanjian. Selain itu, terdapat juga persoalan panjangnya jalur birokrasi internal yang harus ditempuh oleh setiap negara berdasarkan sistem konstitusinya masing-masing. Faktor politik internal maupun eksternal juga turut berpengaruh terhadap sikap dan tindakan setiap negara dalam hubungan-hubungan internasional, termasuk dalam menghadapi suatu perjanjian internasional. Hal ini menimbulkan efek bahwa ada negara yang sangat lambat dalam mengesahkan perjanjian, dan sebaliknya, ada juga negara yang dalam tempo cepat sudah mengesahkannya, bahkan ada juga yang tidak mau sama sekali. Lihat, I Wayan Parthiana, Hukum Perjanjian Internasional Bagian 1..., op.cit., hal. 135-136; Lihat juga, Sefriani, Hukum Internasional..., op.cit., hal. 33; J.G. Starke, Pengantar Hukum Internasional 2..., op.cit., hal. 607.

30 Boer Mauna, Hukum Internasional Pengertian, Peranan..., op.cit. 
Perjanjian Internasional menentukan, "pengesahan adalah perbuatan hukum untuk mengikatkan diri pada suatu perjanjian internasional dalam bentuk ratifikasi (ratification), aksesi (accession), penerimaan (acceptance) dan penyetujuan (approval)". Berdasarkan uraian pasal tersebut terlihat bahwa ratifikasi merupakan salah satu cara pengesahan perjanjian internasional.

Dalam hal perjanjian wajib disahkan, maka penandatanganan perjanjian belum menciptakan ikatan hukum kepada peserta. Sebaliknya, bila tidak ada kewajiban pengesahan, maka perjanjian dianggap mengikat setelah ditandatangani. Cara ratifikasi lebih sering digunakan dalam praktik pengesahan perjanjian internasional sehingga eksistensinya lebih melembaga dibandingkan dengan cara-cara pengesahan lainnya. ${ }^{31}$ Dalam tulisan ini, pembahasan difokuskan pada pengesahan perjanjian internasional dalam artian ratifikasi.

Adanya klausula ratifikasi dalam suatu perjanjian internasional menimbulkan tenggat waktu antara penandatanganan dengan peratifikasian. Tenggat waktu tersebut sebenarnya terkait erat dengan urgensitas ratifikasi itu sendiri. Dalam sejarahnya, prosedur ratifikasi secara progresif dimulai pada pertengahan abad ke XIX. Sebelumnya, utusan yang diberi kekuasaan penuh oleh Raja dapat menandatangani perjanjian dan langsung mengikat negara secara definitif. ${ }^{32}$ Urgensi ratifikasi menjadi niscaya karena kepala negara dalam perkembangannya merasa perlu untuk meyakinkan dirinya bahwa utusan telah diberi kuasa penuh olehnya tidak melampaui batas wewenangnya. ${ }^{33}$

31 Secara umum, antara ratification (ratifikasi), acceptance (akseptasi), accession (aksesi), approval (persetujuan) memiliki pengertian sama, yaitu pengesahan. Namun, secara khusus memang terdapat perbedaan teknis antara istilah-istilah tersebut.

a. Dalam ratifikasi, maka negara yang mengesahkan perjanjian internasional adalah negara penandatangan perjanjian tersebut. Dengan perkataan lain, negara bersangkutan merupakan negara yang ikut aktif dalam tahap-tahap pembuatan perjanjian, dari mulai perundingan hingga penandatanganan.

b. Dalam aksesi atau persetujuan, negara yang mengesahkan perjanjian internasional adalah negara yang sebelumnya tidak menandatangani perjanjian. Hal ini berart, negara tersebut tidak mengikut tahap-tahap pembuatan perjanjian. Namun, di kemudian hari negara bersangkutan berniat untuk turut serta (mengikatkan diri) ke dalam perjanjian tersebut. Perjanjian internasional yang bisa di aksesi adalah perjanjian-perjanjian internasional yang materinya umum dan mendasar, seperti masalah lingkungan hidup, perang, hubungan diplomatik, laut, udara dan ruang angkasa dan lain sebagainya.

c. Terkait dengan akseptasi, di bidang internasional tidak ada perbedaan antara ratifikasi dengan akseptasi. Istilah akseptasi ini dipakai baru semenjak beberapa dekade terakhir. Hanya kadang-kadang terdapat perbedaan di dalam konteks hukum nasional, di mana formalitas akseptasi lebih sederhana dari formalitas ratifikasi. Namun, tidak ada peraturan yang jelas mengenai perbedaan pemakaian kedua istilah tersebut secara hukum nasional, semuanya tergantung isistem konstitusional masing-masing negara. Akseptasi pernah digunakan Indonesia dalam MoU ASEAN on the Trans ASEAN Gas Pipeline Project, 2002, yang disahkan melalui Instrument of Acceptance.

Ibid., hal. 121. Lihat juga, J.G. Starke, Pengantar Hukum Internasional 2..., op.cit., hal. 603; Damos Dumoli Agusman, Hukum Perjanjian Internasional..., op.cit., hal. 88.

32 Boer Mauna., Hukum Internasional Pengertian, Peranan..., op.cit., hal. 117.

33 Setyo Widagdo, Masalah-Masalah Hukum Internasional Publik, (Malang : Bayu Media, 2008), hal. 3. 
Setelah itu, barulah negara mengkonfirmasi tindakan utusannya yang telah menandatangani perjanjian dan sebagai implikasinya, negara resmi terikat dengan perjanjian. ${ }^{34}$ Kesulitan mengadakan hubungan yang cepat pada waktu itu sehingga kepala negara atau pemerintah yang bersangkutan tidak dapat terus menerus mengikuti langkah utusan yang dikirimnya, juga turut mendorong urgensi ratifikasi. Namun demikian, pada zaman yang modern ini dengan bertambah mudahnya perhubungan berkat kemajuan teknologi, alasan sulitnya komunikasi sudah jauh berkurang. ${ }^{35}$

Dalam perkembangan selanjutnya, dengan mundurnya monarki absolut, dan berkembangnya pemerintahan demokratis, kini ratifikasi menjadi suatu cara bagi lembaga perwakilan rakyat untuk meyakinkan dirinya bahwa wakil pemerintah (eksekutif) yang turut serta dalam perundingan dan menandatangani suatu perjanjian tidak keluar dari instruksi atau melakukan hal yang dianggap bertentangan dengan kepentingan umum. ${ }^{36}$

Di negara-negara dengan sistem representatif, di mana badan-badan legislatif hasil pemilu dilibatkan dalam proses pembuatan perjanjian, maka pemeriksaan kembali naskah perjanjian secara konstitusional dianggap perlu. Kalau tidak, peranan parlemen dalam proses pembuatan perjanjian tidak ada artinya karena mulai dari berunding sampai pada penandatanganan hanya dilakukan oleh utusan-utusan pemerintah (eksekutif) dan badan legislatif tidak ikut dilibatkan. Itulah sebabnya, mengapa ratifikasi dianggap perlu dan yang akhirnya merupakan praktik yang berlaku umum. ${ }^{37}$

Dengan demikian, pelibatan parlemen pembuatan traktat telah menimbulkan pengertian bahwa tandatangan saja tidak cukup untuk membuat perjanjian mengikat negara. Sesudah penandatanganan harus ada ratifikasi dan barulah sesudah ratifikasi itu negara dapat diikat secara definitif oleh suatu perjanjian. Pembedaan antara tandatangan dan ratifikasi mempunyai arti penting dan sejalan dengan prinsip-prinsip modern hukum publik yang tidak menerima pelimpahan wewenang tanpa pengecekan. Pengecekan ini tidak akan menimbulkan masalah diplomatik mengingat perjanjian yang ditandatangani tersebut belum diterima secara definitif, tenggat waktu antara

34 Damos Dumoli Agusman, Hukum Perjanjian Internasional..., op.cit., hal. 71. Lihat juga, J.G. Starke, Pengantar Hukum Internasional 2..., op.cit., hal. 601.

35 Mochtar Kusuma'atmadja dan Etty R. Agoes, Pengantar Hukum Internasional..., op.cit., hal. 130.

36 Ibid. Lihat juga, Setyo Widagdo, Masalah-Masalah Hukum Publik Internasional..., op.cit., hal. 4.

${ }^{37}$ Boer Mauna, Hukum Internasional Pengertian, Peranan..., op.cit., hal. 118. 
penandatanganan dan ratifikasi dapat digunakan untuk mempelajari lagi naskah perjanjian tersebut sebelum negara mengikatkan diri secara yuridis. ${ }^{38}$

Seiring dengan diakuinya peranan parlemen dalam pembuatan perjanjian internasional, dan dalam rangka hukum nasional (internal) merespons klausul ratifikasi yang disyaratkan oleh perjanjian internasional, maka lembaga ratifikasi ini secara bersamaan berkembang dalam hukum nasional (ketatanegaraan). Di beberapa negara, lembaga ratifikasi secara internal selalu diartikan sebagai persetujuan (approval) parlemen terhadap rencana kepala negaranya (Presiden atau Raja/Ratu) untuk melakukan ratifikasi (eksternal) seperti yang disyaratkan oleh oleh perjanjian itu. Bahkan, dewasa ini persetujuan Parlemen tidak lagi semata-mata dibutuhkan dalam kerangka ratifikasi perjanjian seperti yang diisyaratkan oleh perjanjian itu sendiri, melainkan telah menjadi wewenang dalam kerangka fungsi kontrol terhadap pemerintah. 39

\section{Persentuhan Hukum Tata Negara dan Hukum Internasional dalam Pengaturan dan Praktik Perjanjian Internasional}

Dengan berlangsungnya era globalisasi dan kemajuan teknologi telah mengakibatkan interaksi Indonesia semakin intensif dengan masyarakat internasional. Konsekuensinya, keikutsertaan Indonesia dalam berbagai perjanjian internasional semakin meningkat. Interaksi-interaksi melalui perjanjian internasional selanjutnya akan mengakibatkan meningkatnya persentuhan-persentuhan hukum antara Indonesia dengan negara-negara lainnya dan bahkan dalam tingkat tertentu akan menimbulkan tumpang tindih antara hukum internasional termasuk perjanjian internasional dengan hukum nasional dan akan semakin menepis anggapan bahwa hukum perjanjian internasional hanya milik diplomat saja. ${ }^{40}$

Persentuhan atau interaksi perjanjian internasional dengan hukum nasional terutama sangat kuat dengan bidang hukum tata negara. Terdapat beberapa alasan sehubungan dengan hal tersebut:

1. Perjanjian internasional merupakan materi muatan UUD. Dalam UUD Tahun 1945 pasca perubahan, persoalan perjanjian internasional diatur dalam Pasal 11 ayat (1),

\footnotetext{
38 Ibid., hal. 117-118. Lihat juga, J.G. Starke, Pengantar Hukum Internasional 2..., op.cit., hal. 601.

39 Damos Dumoli Agusman, Hukum Perjanjian Internasional..., op.cit., hal. 72-73.

40 Ibid., hal. 3.
} 
(2) dan (3). Dengan demikian, hukum dasar secara tegas mengakui eksistensi perjanjian internasional dalam lingkungan hukum nasional;

2. Perjanjian internasional merupakan salah satu sumber hukum tata negara formal; ${ }^{41}$

3. Dalam tahap-tahap ratifikasi perjanjian internasional terdapat prosedur ketatanegaraan atau persyaratan konstitusional yang harus dipenuhi. Tahap internal ini menyangkut pembagian kekuasaan antara lembaga legislatif dan eksekutif (DPR dan Presiden). Presiden (pemerintah) memiliki kewenangan untuk membuat traktat (treaty making power) sedangkan DPR sebagai badan perwakilan rakyat memiliki kewenangan untuk menyetujui atau menolak traktat yang telah dibuat oleh pemerintah.

Terkait dengan itu, menurut Logemann, ilmu hukum tata negara dalam arti sempit menyelidiki hal-hal antara lain :

a. Jabatan-jabatan yang terdapat di dalam susunan kenegaraan tertentu;

b. Siapa yang mengadakannya;

c. Bagaimana cara memperlengkapi mereka dengan pejabat-pejabat;

d. Apa yang menjadi tugasnya (lingkungan pekerjaannya);

e. Apa yang menjadi wewenangnya;

f. Perhubungan kekuasaan satu sama lainnya;

g. Di dalam batas-batas apa organisasi negara (dan bagian-bagiannya) menjalankan tugasnya. ${ }^{42}$

Poin 4 dan 5 berbicara mengenai tugas (lingkungan pekerjaan) dan kewenangan lembaga negara. Dalam kaitan dengan traktat, lingkungan pekerjaan Presiden adalah sebagai lembaga eksekutif dan memiliki kewenangan antara lain untuk membuat traktat. Adapun lingkungan pekerjaan DPR adalah sebagai badan legislatif dan memiliki kewenangan antara lain menyetujui atau menolak traktat yang sudah dibuat. Jadi, apabila bersandar kepada pendapat Logemann, maka tugas dan wewenang Presiden dan DPR dalam bidang perjanjian internasional jelas merupakan objek kajian dari hukum tata negara.

Perlu mendapat penekanan di sini, bahwa kewenangan membuat traktat merupakan kewenangan eksklusif Presiden. Namun, di Indonesia pernah terjadi

\footnotetext{
41 Bagir Manan, Konvensi Ketatanegaraan (Bandung : Armico, 1987), hal. 15. Lihat juga, Jimly Asshiddiqie, Pengantar Hukum Tata Negara Jilid 1 (Jakarta : Sekjen MK-RI, 2006), hal. 182.

42 J.H.A Logemann, Over de Theorie van een Stellig Staatsrecht (Tentang Teori Suatu Hukum Tata Negara Positif), diterjemahkan oleh J.C. Pangkerego (Jakarta : Ichtiar Baru - van Hoeve, 1975), hal. 106-107, 117-162. Lihat juga, Ni'matul Huda, Hukum Tata Negara Indonesia (Jakarta : PT RajaGrafindo Persada, 2005), hal. 8.
} 
praktik yang unik, di mana justru DPR yang berinisiatif duluan untuk meratifikasi suatu perjanjian internasional, yakni Convention Against Torture and Other Cruel, Inhuman or Degrading Treatment or Punishment melalui UU No. 5 Tahun 1998. 43 Desakan untuk hak inisiatif DPR ini dipicu oleh situasi politik saatitu (menjelang era reformasi) di mana terjadi maraknya penculikan dan penyiksaan para aktivis reformasi oleh oknum aparat negara. Pada proses akhir approval konvensi ini di Sidang Pleno DPR, wakil pemerintah membuat pernyataan bahwa penggunaan hak inisiatif DPR semacam ini adalah untuk yang pertama dan terakhir kalinya karena kewenangan membuat perjanjian internasional tidak berada pada badan legislatif melainkan pada badan eksekutif. Selanjutnya, ditambahkan pula bahwa di negara yang sangat demokratis sekalipun seperti Amerika Serikat, tidak pernah terjadi bahwa inisiatif pengesahan perjanjian dilakukan oleh badan legislatif. ${ }^{44}$

Dari uraian di atas, maka jelaslah bahwa persoalan traktat bukanlah eksklusif persoalan hukum internasional, melainkan lebih mengarah kepada persentuhan hukum internasional dan hukum tata negara.

4. Lahirnya Lembaga Negara Mahkamah Konstitusi (MK) di Indonesia memunculkan persoalan hukum tata negara, apakah MK dapat menguji substansi traktat melalui undang-undang prosedur internal (undang-undang approval DPR)?

Sejalan dengan itu, menurut Jimly Asshiddiqie : ${ }^{45}$

Para mahasiswa hukum harus menangkap pula kecenderungan baru di mana hukum tata negara sebagai bidang hukum yang bersifat internal suatu negara mulai menyatu atau setidaknya saling pengaruh mempengaruhi dengan bidang kajian hukum internasional publik. Hukum tata negara meluas dari sempitnya orientasi selama ini yang hanya bersifat internal ke arah orientasi eksternal, sehingga ilmu hukum tata negara di samping harus dipelajari sebagai bidang ilmu hukum tata negara positif, juga harus dipelajari sebagai bidang ilmu tata negara umum.

Di halaman yang lain beliau juga mengatakan :

“... Konsep-konsep hukum internasional publik akan semakin mendekat ke arah konsep-konsep hukum tata negara yang sebelumnya hanya bekerja di sekitar aspek-aspek internal saja dari organisasi negara". 46

43 LN Tahun 1998 No.164 TLN No. 3783.

44 Damos Dumoli Agusman, Hukum Perjanjian Internasional..., op.cit., hal. 91-92.

45 Jimly Asshiddiqie, Pengantar IImu Hukum Tata Negara 1..., op.cit., hal. 6.

46 Ibid., hal. 69. 
Sayangnya, di Indonesia kajian hukum tata negara sibuk berkutat dengan domainnya sendiri. Sekalipun perjanjian internasional telah memiliki dasar konstitusional yang kuat dalam Pasal 11 UUD Tahun 1945, namun tampaknya kajian hukum tata negara tentang perjanjian internasional masih sangat minim. Sekalipun para pakar hukum tata negara Indonesia secara tegas mengakui bahwa traktat adalah salah satu sumber hukum tata negara, namun kajian tentang traktat tersebut masih sangat terbatas. Hal ini mengakibatkan:

1. Adanya benang terputus (missing link) antara perjanjian internasional dengan hukum nasional. Sekalipun hukum Indonesia mengenal konsepsi perjanjian internasional (traktat) dan ratifikasi (pengesahan) namun konsepsi ini tidak memiliki akar hukum yang tegas dalam hukum tata negara Indonesia. 47 Padahal, masalah traktat terlebih bagian ratifikasinya sangat kuat bersentuhan dengan hukum tata negara, ataupun merupakan kolaborasi antara hukum tata negara dengan hukum internasional.

2. Kurang jelasnya status perjanjian internasional sebagai sumber hukum positif dalam hukum nasional.

Oleh sebab itu, perlu ada elaborasi lebih jauh untuk menjembatani antara persoalan traktat ini dengan kajian hukum tata negara Indonesia.

\section{E. Ratifikasi Internal dan Eksternal terhadap Perjanjian Internasional Pasca Terbitnya Putusan MK No. 13/PUU-XVI/2018}

Seperti telah dikemukakan di atas, persoalan ratifikasi merupakan wilayah "kolaborasi" antara hukum tata negara dan hukum internasional. Pada prinsipnya, ratifikasi merupakan istilah yang dikenal dalam hukum internasional sehingga tindakan ratifikasi pun disebut sebagai tindakan hukum internasional. Namun, ternyata ratifikasi juga telah berinteraksi dengan prosedur nasional ketatanegaraan suatu negara. Oleh sebab itu, untuk menjernihkan konsepsi ratifikasi maka perlu dibedakan 2 (dua) prosedur berikut ini yang terpisah namun terkait satu sama lain :

1. Dari perspektif prosedur internal, ratifikasi perjanjian internasional adalah masalah hukum tata negara, yaitu hukum nasional Indonesia yang mengatur tentang 
pembagian kewenangan eksekutif dan legislatif dalam pembuatan perjanjian internasional serta mengatur produk hukum apa yang harus dikeluarkan untuk menjadi dasar Indonesia melakukan prosedur eksternal.

Dalam hal ini, prosedur internal secara teknis berisi tindakan hukum internal berupa persetujuan yang diberikan oleh lembaga negara (pada umumnya parlemen) kepada kepala negara/kepala pemerintah untuk melakukan pengikatan diri (ratifikasi) kepada suatu perjanjian. Produk dari perbuatan ini dapat berupa undangundang (act) atau instrumen lain. Di Indonesia ada pula perjanjian internasional yang cukup disetujui oleh Presiden sebelum diratifikasi, tanpa perlu adanya persetujuan DPR, dengan output peraturan presiden. Prosedur internal inilah yang penulis maksud dalam penelitian ini sebagai proses hukum tata negara dalam ratifikasi perjanjian internasional.

2. Adapun dari perspektif prosedur eksternal, maka ratifikasi perjanjian internasional adalah the international act so named whereby a state establishes on the international plane its consent to be bound by a treaty (tindakan internasional dengan cara mana suatu negara dalam taraf internasional menetapkan persetujuannya untuk diikat oleh perjanjian), atau tindakan konfirmasi dari suatu negara terhadap perbuatan hukum pejabatnya yang telah menandatangani suatu perjanjian. Prosedur eksternal validitasnya diatur oleh hukum internasional dan pada tahap ini perjanjian internasional mulai mengikat negara peserta.

Dalam hal ini, prosedur eksternal secara teknis berisi tindakan ratifikasi (pengesahan) oleh kepala negara/pemerintah terhadap perjanjian yang mensyaratkan ratifikasi. Produk perbuatan ini berbentuk instrument of ratification atau Piagam Ratifikasi yang ditandatangani atas nama kepala negara/pemerintah. Apabila ditelaah secara lebih mendalam lagi, dalam prosedur eksternal ini sebenarnya masih terdapat peranan hukum tata negara, yaitu saat penerbitan Piagam Ratifikasi oleh Menteri Luar Negeri atas nama Presiden. Tindakan Penerbitan Piagam tersebut didasarkan atas kewenangan lembaga negara yang berada dalam domain hukum tata negara. Adapun tindakan selanjutnya berupa pertukaran atau penyimpanan Piagam Ratifikasi sudah merupakan murni domain hukum internasional.

Pengaturan dan praktik di Indonesia dewasa ini ternyata cenderung mencampuradukkan prosedur internal dan prosedur eksternal dalam ratifikasi 
perjanjian internasional. Mochtar Kusuma'atmadja juga mengakui hal itu dengan mengatakan :

Mengenai ratifikasi perjanjian internasional ini ada beberapa hal yang menyebabkan ketidakpastian atau kekaburan. Satu di antaranya ialah tidak dibedakannya 2 (dua) tahap dalam proses ratifikasi ini yaitu pemberian persetujuan (apporval) dan tindakan pengesahan atau ratifikasi itu sendiri. Sering dipergunakan kata ratifikasi untuk mencakup seluruh proses yang meliputi kedua tahap yang tersebut tadi. 48

Oleh sebab itu, tidak ada pembedaan yang tegas antara tahap persetujuan (prosedur internal) dengan tahap ratifikasi itu sendiri (prosedur eksternal). Akibatnya, timbul ketidakpastian, kekaburan atau distorsi dalam konsepsi ratifikasi, di mana prosedur internal ternyata telah dipahami sebagai tindakan ratifikasi itu sendiri. Padahal, prosedur internal itu bukanlah tindakan ratifikasi, melainkan suatu proses konstitusional yang pemenuhannya dipersyaratkan untuk melakukan tindakan ratifikasi yang sebenarnya.

Secara lebih konkrit, seperti juga telah diutarakan di atas, bahwa output dari prosedur internal adalah undang-undang atau peraturan presiden. Adanya kekaburan dalam konsepsi ratifikasi telah menimbulkan pemahaman yang keliru bahwa undangundang atau peraturan presiden itulah yang meratifikasi (mengikatkan Indonesia kepada) perjanjian internasional. Akibatnya, undang-undang atau peraturan presiden prosedur internal selalu memiliki judul "mengesahkan perjanjian." Sebagai contoh, UU No. 42 Tahun 2007 tentang Pengesahan Perjanjian Ekstradisi antara Republik Indonesia dan Republik Korea. Jelas sekali dalam judul tersebut, bahwa undangundang itulah yang telah mengesahkan perjanjian internasional.

Undang-undang atau peraturan presiden tersebut tidaklah meratifikasi perjanjian internasional, tetapi lebih kepada instrumen yang menampung persetujuan terhadap rencana untuk meratifikasi perjanjian internasional tersebut. Oleh sebab itu, seharusnya judul undang-undang atau peraturan presidennya bukan tentang "pengesahan perjanjian", tetapi undang-undang atau peraturan presiden tentang "memberi persetujuan" atau tentang "persetujuan terhadap perjanjian...".

Dalam tahap berikutnya, undang-undang atau peraturan presiden tersebut akan menjadi acuan untuk melakukan prosedur eksternal, yaitu tindakan ratifikasi itu 
sendiri. Dengan perkataan lain, undang-undang atau peraturan presiden tersebut akan menjadi dasar hukum bagi Menteri Luar Negeri untuk menerbitkan Piagam Ratifikasi. Tanpa adanya instrumen undang-undang atau peraturan presiden tersebut, Menteri Luar Negeri tidak dapat mengeluarkan Piagam dimaksud. Selanjutnya, Piagam tersebut akan ditukarkan dengan negara mitra atau disimpan di negara/organisasi internasional yang ditunjuk sebagai penyimpan (prosedur eksternal). Pertukaran/penyimpanan Piagam itulah yang dikatakan tindakan ratifikasi dalam konteks international act. Dengan peristiwa tersebut, perjanjian internasional resmi mengikat negara.

Kekeliruan lainnya lagi yang timbul sebagai implikasi undangundang/peraturan presiden prosedur internal dipandang sebagai instrumen yang meratifikasi perjanjian internasional adalah bahwa instrumen tersebut dianggap pula sebagai undang-undang/peraturan presiden substansial yang menampung isi perjanjian. Dalam hal ini, penulis menegaskan bahwa undang-undang/peraturan presiden prosedur internal bukanlah undang-undang/peraturan presiden substansial, tetapi merupakan undang-undang/peraturan presiden prosedural (formal) yang merupakan "jubah” dari persetujuan DPR/Presiden. Dengan kata lain, undang-undang/peraturan presiden tersebut tidak menampung isi perjanjian internasionalnya. Isi perjanjian tersebut ditampung dalam undang-undang tersendiri yang dalam teori hukum perjanjian internasional disebut implementing legislation (undang-undang implementasi), yang diciptakan setelah perjanjian internasional diratifikasi.

Masalah kekaburan tahap-tahap ratifikasi perjanjian internasional di Indonesia sebenarnya tidak terlepas dari cacat yang terdapat di dalam Pasal 11 UUD Tahun 1945. Pasal tersebut hanya menyinggung persetujuan DPR dalam membuat perjanjian internasional, tetapi sama sekali tidak menyinggung ratifikasi. Akibatnya, muncul pemahaman bahwa persetujuan DPR itulah yang meratifikasi perjanjian internasional dengan output berupa undang-undang ratifikasi. Implikasi lebih jauh, undang-undang organiknya yaitu UU No. 24 Tahun 2000 tentang Perjanjian Internasional juga memiliki sikap bahwa undang-undang atau peraturan presidenlah yang mengesahkan perjanjian internasional (lihat Pasal 9 ayat (2), Pasal 10 dan Pasal 11). Hal yang berbeda justru ditemui pada Konstitusi RIS dan UUDS 1950. Kedua 
hukum dasar tersebutmembedakan secara tegas antara tahap persetujuan (approval) dan tahap pengesahan (ratification).

Terbitnya Putusan MK No. 13/PUU-XVI/2018 tentang Pengujian UU No. 24 Tahun 2000 tentang Perjanjian Internasional terhadap UUD telah menimbulkan perkembangan/perspektif baru terkait dengan ratifikasi perjanjian internasional ini. Tampaknya MK ingin memberikan penafsiran lebih jauh untuk memperjelas Pasal 11 ayat (1) dan Pasal 11 ayat (2) UUD Tahun 1945. Pertama, Putusan ini menyatakan Pasal 10 UU No. 24 Tahun 2000 tentang Perjanjian Internasional tidak memiliki kekuatan mengikat. Pasal 10 tersebut berisi tentang 6 (enam) bidang Perjanjian Internasional yang harus disetujui oleh DPR, yaitu :

1. Masalah politik, perdamaian, pertahanan, dan keamanan negara;

2. Perubahan wilayah atau penetapan batas wilayah negara Republik Indonesia;

3. Kedaulatan atau hak berdaulat negara;

4. Hak asasi manusia dan lingkungan hidup;

5. Pembentukan kaidah hukum baru;

6. Pinjaman dan/atau hibah luar negeri.

Oleh MK, Pasal 10 tersebut dianggap bertentangan dengan Pasal 11 ayat (2) UUD Tahun 1945, sehingga kriteria perjanjian internasional yang memerlukan persetujuan DPR dikembalikan kepada Pasal 11 ayat (2) yaitu Presiden dalam membuat perjanjian internasional lainnya yang menimbulkan akibat yang luas dan mendasar bagi kehidupan rakyat yang terkait dengan beban keuangan negara, dan/atau mengharuskan perubahan atau pembentukan undang-undang harus dengan persetujuan Dewan Perwakilan Rakyat". Kriteria general dalam Pasal 11 ayat (2) ini lebih fleksibel untuk menentukan bidang-bidang mana saja yang dianggap memerlukan persetujuan DPR sesuai dengan kepentingan nasional, tidak terbatas pada 6 (enam) bidang yang ditentukan dalam Pasal 10 UU No. 24 Tahun 2000 tersebut.

Kedua, MK memberikan perumusan yuridis baru dalam proses approval (persetujuan DPR) dan munculnya istilah "pengesahan perjanjian internasional oleh hukum nasional". Praktik yang terjadi selama ini cenderung mencampur (menyatukan) antara tahap persetujuan DPR dengan tahap keluarnya UU Ratifikasi. 
Artinya, persetujuan DPR diekspresikan dengan keluarnya UU Ratifikasi. MK tampaknya memberikan tafsir lain dengan membedakan dua tahap itu.

1. Tahap persetujuan DPR, yang diperoleh melalui "rekomendasi" DPR yang terbit melalui rapat-rapat konsultasi antara DPR dengan Pemerintah;

2. Tahap pengesahan perjanjian internasional oleh hukum nasional, yaitu dengan terbitnya UU Ratifikasi.

Namun perlu dipahami, pembagian yang dilakukan MK khususnya pada tahap kedua yaitu "pengesahan perjanjian internasional oleh hukum nasional" tidak serta merta dapat diartikan bahwa perjanjian internasional tersebut langsung mengikat Indonesia, karena sebenarnya ini baru merupakan ratifikasi internal. Masih ada tahap selanjutnya sebelum perjanjian mengikat, yaitu ratifikasi eksternal berupa :

1. Pembuatan Piagam Ratifikasi oleh Menteri Luar Negeri;

2. Pengiriman dan penyimpanan Piagam Ratifikasi di negara penyimpan.

Pada prinsipnya, ratifikasi eksternal inilah yang justru menjadi patokan berlakunya suatu perjanjian internasional (enter into force), kecuali ditentukan lain oleh perjanjian tersebut (misalnya untuk berlakunya perjanjian tersebut memerlukan jumlah tertentu ratifikasi eksternal dari negara peserta). Oleh karena itu, konstruksi MK tentang "pengesahan perjanjian internasional oleh hukum nasional harus dipahami sebagai ratifikasi internal yang belum menandai berlakunya perjanjian internasional, karena masih harus dilanjutkan dengan tahap ratifikasi eksternal.

\section{F. Transformasi Ketentuan Perjanjian Internasional ke dalam Perundang-undangan Nasional}

Untuk Perjanjian internasional yang bersifat law making (meletakkan kaidah hukum pada masyarakat internasional), maka setelah diratifikasi perlu ditransformasikan lebih lanjut ke dalam hukum nasional, dengan membentuk peraturan perundang-undangan yang memungkinkan untuk implementasinya (implementing legislation). Hal itu karena :

1. Materi muatan perjanjian law making biasanya mengatur bidang-bidang yang umum dan mendasar, seperti masalah perang (konflik bersenjata), HAM, larangan perbudakan, larangan diskriminasi ras, larangan penyiksaan, hukum udara dan ruang angkasa, hukum laut lingkungan hidup, genosida, lingkungan hidup, hubungan 
diplomatik dan konsuler, aliansi militer, ekstradisi, hukum perjanjian dan sebagainya. Selain itu, dilihat dari jumlah pesertanya, perjanjian-perjanjian law making pada umumnya melibatkan banyak negara (multilateral universal), kecuali perjanjian ekstradisi yang biasanya berupa perjanjian bilateral. Perjanjian semacam ini juga digolongkan sebagai non self executing, sehingga apabila tidak dibentuk undangundang implementasinya, maka akan sulit dilaksanakan di dalam negeri. Apalagi para aparat selalu mengacu kepada peraturan perundang-undangan nasional, dan bukan kepada perjanjian internasionalnya;

2. Beberapa ketentuan (provisi) perjanjian internasional law making juga acapkali meminta dibentuknya legislasi nasional untuk menjabarkan lebih lanjut objek dan tujuan perjanjian;

3. Perjanjian-perjanjian law making memiliki potensi untuk berbenturan dengan undang-undang nasional yang telah ada lebih dahulu, karena itu undang-undang implementasi berperan untuk mengamandemen ketentuan undang-undang nasional yang bertentangan dengan perjanjian internasional.

4. Perjanjian law making adakalanya berisi ketentuan yang belum diatur dalam hukum nasional, karena itu hal yang belum diatur tersebut harus diadakan pengaturannya. Sebagai contoh, dalam Konvensi Anti Korupsi PBB 2003 terdapatketentuan mengenai penyuapan terhadap pejabatasing. Indonesia sebagai peserta konvensi tersebuttentu perlu mengakomodasi masalah penyuapan terhadap pejabat asing tersebut dengan melakukan penyempurnaan pada UU TIPIKOR.

Sedangkan untuk perjanjian-perjanjian aplikatif yang sifatnya sederhana tidak perlu lagi dilengkapi dengan undang-undang implementasi, karena perjanjian tersebut pada dasarnya bersifat self executing.

\section{G. Kewenangan MK dalam Menguji Substansi Perjanjian Internasional melalui Undang-Undang Prosedur Internal}

Mahkamah Konstitusi (MK) tidak dapat menguji materiil substansi perjanjian internasional melalui undang-undang prosedur internal (undang-undang approval DPR) karena:

1. Undang-undang tersebut hanya mengukuhkan persetujuan DPR terhadap rencana pemerintah untuk meratifikasi perjanjian internasional; 
2. Dengan demikian, undang-undang tersebut dikategorikan sebagai undang-undang “jubah" persetujuan DPR (undang-undang formal/prosedural), bukan undangundang substansial yang menampung isi perjanjian internasional.

Dalam hal MK menguji langsung naskah traktatnya, maka hal itu pun tidak bisa dilakukan karena yang berwenang menilai dan menafsirkan perjanjian internasional adalah Mahkamah Internasional. Adapun MK tidak memiliki kewenangan semacam itu. Yang dapat dilakukan MK adalah dengan menguji undang-undang implementasi dari perjanjian internasional tersebut. Dalam hal MK menyatakan bahwa ketentuan undang undang implementasinya bertentangan dengan UUD Tahun 1945, sehingga diputuskan tidak memiliki kekuatan mengikat lagi, maka menimbulkan implikasi bahwa ketentuan perjanjian internasionalnya tetap memiliki daya laku, tetapi daya gunanya sudah dilumpuhkan. Akibatnya, ketentuan perjanjian tersebut tidak dapat bekerja secara ef ektif lagi dalam kehidupan berbangsa dan bernegara.

Namun demikian, cara tersebut memiliki risiko berupa timbulnya masalah lanjutan dengan hukum dan masyarakat internasional. Menurut Konvensi Wina 1969 tentang Hukum Perjanjian, hukum nasional tidak dapat dijadikan pembenaran untuk menghindar dari pemenuhan kewajiban perjanjian internasional. Selain itu, negara peserta lain yang telah melaksanakan perjanjian internasional tersebut dengan itikad baik juga akan mempertanyakan, memprotes bahkan menggugat Indo nesia. Oleh sebab itu, jalan yang relatif lebih aman adalah memastikan sejak awal bahwa ketentuan perjanjian internasional tersebut tidak bertentangan dengan UUD Tahun 1945.

Sejalan dengan itu Jimly Asshiddiqie mengatakan: 49

Hukum internasional agar dapat mengikat di dalam negeri lebih dulu diratifikasi dan ditundukkan di bawah UUD Tahun 1945. Jika (i) belum diratifikasi tentu belum mengikat, dan tetapi juga (ii) tidak boleh bertentangan dengan UUD baik isinya maupun proses ratifikasinya.

Berdasarkan pendapat tersebut, maka sebelum traktat diratifikasi harus diteliti dengan sungguh-sungguh apakah ketentuannya bertentangan atau tidak dengan ketentuan UUD Tahun 1945. Untuk itu, perlu diperhatikan hal-hal sebagai berikut:

1. Kriteria juru runding

49 Tanya Jawab Penulis dengan Jimly Asshiddiqie melalui www.jimly.com pada hari Sabtu, 10 September 2010, terakhir dikunjungi pada tanggal 13 Juni 2011. 
Seperti dikatakan oleh Himahanto Juwana, para juru runding (delegasi) Indonesia harus memiliki kelihaian dalam merundingkan dan merumuskan traktat, terutama dalam memahami kalimat-kalimat hukum di dalam naskah traktat. 50 Dengan kelihaian ini, diharapkan sejak awal sudah dapat diketahui ketentuanketentuan yang berpotensi bertentangan dengan UUD.

2. Fungsi legislative preview

DPR sebagai lembaga negara yang memberikan persetujuan terhadap rencana ratifikasi traktat, juga harus mem-preview secara memadai naskah traktat yang telah ditandatangani, dan jangan serta merta memberikan persetujuan untuk meratifikasi traktat tersebut. Bila ternyata kemudian diyakini bertentangan dengan UUD tahun 1945, maka Indonesia segera dapat mengajukan reservasi (pensyaratan) terhadap ketentuan tersebut atau mengambil kebijakan untuk tidak jadi meratifikasi perjanjian internasional tersebut sama sekali.

\section{H. Penutup}

1. Persetujuan DPR pada Pasal 11 UUD Tahun 1945 harus dimaknai sebagai wewenang DPR untuk menyetujui atau tidak menyetujui rencana Presiden untuk mengikatkan diri pada perjanjian internasional. Persetujuan DPR tidak lagi diartikan sebagai pengesahan perjanjian internasional melainkan dilihat sebagai bagian dari persyaratan konstitusional dalam proses pembuatan perjanjian. Untuk itu, persetujuan DPR ini sebaiknya diartikan secara harfiah. Sekalipun persetujuan ini dituangkan dalam format undang-undang, maka tanggal mulai berlakunya undangundang ini tidak memiliki arti hukum bagi pemberlakuan perjanjian itu sendiri.

MK dalam Putusan No. 13/PUU-XVI/2018 telah memberikan khazanah baru dalam menafsirkan lebih lanjut Pasal 11 ayat (1) dan (2) UUD Tahun 1945. Termasuk, membedakan antara proses persetujuan DPR dengan pengesahan perjanjian internasional oleh hukum nasional yang dalam praktik selama ini keduanya dicampur aduk. Namun konsep "pengesahan perjanjian internasional oleh hukum nasional tidak dapat diartikan sebagai mulai berlakunya perjanjian tersebut, karena masih ada mekanisme (ratifikasi) eksternal yang masih harus ditempuh yaitu pembuatan 
Piagam Ratifikasi, Pengiriman dan Penyimpanan Piagam Ratifikasi di Negara Penyimpan.

2. Diperlukan adanya juru runding handal yang mampu membaca kalimat-kalimat hukum dalam perjanjian internasional dengan baik, sehingga sejak dini dapat diketahui indikasi pertentangan antara ketentuan perjanjian internasional dengan UUD Tahun 1945;

3. Dalam hal Pemerintah Indonesia mengambil kebijakan untuk meratifikasi perjanjian internasional, maka harus siap untuk menerima segala konsekuensi hukumnya. Untuk itu, perlu dipenuhi hal-hal sebagai berikut :

a. Membentuk undang-undang yang mengimplementasikan (mentransformasikan) perjanjian tersebut. Dalam hal DPR dan pemerintah lamban dan kurang responsif dalam upaya transformasi yang disyaratkan maka Indonesia akan dikatagorikan sebagai negara yang tidak dapat memegang komitmen atau janjinya;

b. Menjalankan perjanjian internasional dengan itikad baik, karena negara peserta akan dipantau oleh badan pengawas yang dibentuk oleh perjanjian internasional tersebut, termasuk memberikan laporan mengenai progress pelaksanaan perjanjian. Sebagai contoh, pelaksanaan konvensi HAM diawasi oleh Ko misi HAM PBB.

c. Meningkatkan kapasitas aparat penegak hukum. Hal ini karena bila perjanjian internasional telah diterjemahkan ke dalam hukum nasional namun tidak mampu ditegakkan oleh aparat maka sama saja Indonesia tidak menepati komitmennya. Dengan konsekuensi yang cukup berat ini, maka Indonesia harus memikirkan dengan masak-masak dalam hal hendak meratifikasi perjanjian internasional.

4. Dalam hal Pemerintah Indonesia mengambil kebijakan untuk tidak jadi meratifikasi perjanjian internasional, maka ketentuan-ketentuan perjanjian internasional tersebut yang dipandang baik tetap dapat diadopsi ke dalam hukum nasional. Dengan melakukan adopsi, setidak-tidaknya Indonesia terhindar dari berbagai konsekuensi apabila ikut meratifikasi. 


\section{SENARAI PUSTAKA}

Asshiddiqie, Jimly. Green Constitution Nuansa Hijau Undang-Undang Dasar Negara Republik Indonesia Tahun 1945. Jakarta : PT RajaGrafindo Persada, 2009.

. Pengantar Hukum Tata Negara Jilid 1. Jakarta : Sekjen MK-RI, 2006.

Daming, Saharuddin. "Sekapur Sirih tentang Pranata Ratifikasi dan Perjanjian Internasional".

http://docs.google.com/viewer?a=v\&q=cache:OyNWWi x0u0J:www.komnasham.go.id Lpublikasi/doc download/47-ratifikasi-ham-oleh-saharuddin-

$\underline{\text { daming }+ \text { proses }+ \text { ratifikasi+perjanjian }+ \text { internasional }+d i+\text { Indonesia\& } h l=i d \& g l=i d \& p i d=}$ $\underline{b l \& \text { srcid }=. ~ D i a k s e s ~ t a n g g a l ~} 3$ Juni 2011.

Dumoli Agusman, Damos. Hukum Perjanjian Internasional Kajian Teori dan Praktik Indonesia. Jakarta : Refika Aditama, 2010.

Huda, Ni'matul. Hukum Tata Negara Indonesia. Jakarta : PT RajaGrafindo Persada, 2005.

I Wayan Parthiana, Pengantar Hukum Internasional. Bandung : Mandar Maju, 2003.

Juwana, Hikmahanto. Hukum Internasional Dalam Perspektif Indonesia Sebagai Negara Berkembang. Jakarta : Yarsif Watampone, 2010.

. "Konsekuensi Ratifikasi Perjanjian Internasional". http://www.seputarindonesia.com/edisicetak/content/view/181327/. Diakses tanggal 23 Januari 2011.

Kusuma'atmadja, Mochtar dan Etty R. Agoes. Pengantar Hukum Internasional. Bandung : Alumni, 2003.

Logemann, J.H.A. Over de Theorie van een Stellig Staatsrecht (Tentang Teori Suatu Hukum Tata Negara Positif), diterjemahkan oleh J.C. Pangkerego. Jakarta : Ichtiar Baru - van Hoeve, 1975.

Manan, Bagir. Konvensi Ketatanegaraan. Bandung : Armico, 1987.

Mauna, Boer. Hukum Internasional Pengertian, Peranan dan Fungsi dalam Era Dinamika Global. Bandung: Alumni, 2000.

Parthiana, I Wayan. Hukum Perjanjian Internasional Bagian 1. Bandung: Mandar Maju, 2002.

Prodjodikoro, Wirjono. Azaz-Azaz Hukum Publik Internasional. Jakarta : Pembimbing Masa, 1967.

Sastroamidjojo, Ali. Pengantar Hukum Internasional. Jakarta : Bhratara, 1971.

Sefriani. Hukum Internasional Suatu Pengantar. Jakarta : PT RajaGrafindo Persada, 2010. 
Slamet Kurnia, Titon. Pengantar Sistem Hukum Indonesia. Bandung : Alumni, 2009.

Starke, J.G. An Introduction to International Law (Pengantar Hukum Internasional) 2, diterjemahkan oleh Bambang Iriana Djajaatmadja. Jakarta : Sinar Grafika, 2003.

Suryokusumo, Sumaryo. Hukum Perjanjian Internasional. Jakarta : PT Tata Nusa, 2008.

Suwardi, Sri Setianingsih. Pengantar Hukum Organisasi Internasional. Jakarta : UI Press, 2004.

Van Hoof, G.J.H. Rethinking The Sources of International Law (Pemikiran Kembali SumberSumber Hukum Internasional), diterjemahkan oleh Hata. Bandung : Alumni, 2000.

W. Janis, Mark. An Introduction to International Law. Boston Toronto : Little Brown and Company, 1988.

Whisnu Situni, F.A. Identifikasi dan Reformulasi Sumber-Sumber Hukum Internasional. Bandung : Mandar Maju, 1989.

Widagdo, Setyo. Masalah-Masalah Hukum Internasional Publik. Malang : Bayu Media, 2008. www.jimly.com. Terakhir dikunjungi pada tanggal 13 Juni 2011. 